\title{
Reduction of Marine Bivalve Mollusc (Anadara granosa) using Impressed Current Anti Fouling (ICAF) to Prevent the Biofouling
}

\author{
Herman Pratikno ${ }^{1 *}$, Harmin Sulistiyaning Titah ${ }^{2}$, Handayanu $^{1}$, Moontera Priyanto ${ }^{1}$ \\ ${ }^{1}$ Department of Ocean Engineering, Faculty of Marine Technology, Sepuluh Nopember \\ Institute of Technology, Keputih, Sukolilo, 60111 Surabaya, Indonesia \\ ${ }^{2}$ Department of Environmental Engineering, Faculty of Civil, Planning and Geo Engineering, \\ Sepuluh Nopember Institute of Technology, Keputih, Sukolilo, 60111 Surabaya, Indonesia
}

\begin{abstract}
Fouling is an adverse problem for ship. Fouling itself is some kind of marine biota like shells, mussels, or barnacles, which grow and live on the surface of ship's hull or inside the ship's piping system. Many methods have been applied to prevent fouling. Impressed Current Anti Fouling (ICAF) was developed and applied as an alternative in mitigation of fouling. The aim of the research was to determine the effects of electrical current, duration time, salinity on Anadara granosa death in simple ICAF system. The simple ICAF reactor was operated in electric current of $1.5 \mathrm{~A}$, and duration time $(1,3,5,7$ dan $9 \mathrm{~h}$ ), variations of salinity (33\%, 35\% and $37 \%$ ) and the size of shell $(1-2 \mathrm{~cm}$ and $2-3 \mathrm{~cm})$. Steel of AH36 has a role as a cathode, meanwhile pure copper $(\mathrm{Cu})$ was an anode. The death of Anadara granosa was conducted using direct observation. The direct observation was carried out by opening the shells one by one. The death of mollusc can be confirmed by looking the response from the mollusc. If the mollusc showed no response when it was pierced, it indicated that the mollusc was dead. Besides that, there was white slime inside the mollusc. Based on the results, the death of Anadara granosa with shell size of 2-3 cm showed the highest percentage of $90 \%$ at electrical current of $1.5 \mathrm{~A}$, duration time of $9 \mathrm{~h}$, and salinity of $37 \%$. Meanwhile the smallest percentage of Anadara granosa death reached $10 \%$ at electrical current of 1.5 A, duration time of $7 \mathrm{~h}$, and salinity of $33 \%$ for shell size of $1-2 \mathrm{~cm}$. In conclusion, duration time and salinity were higher so that the death of Anadara granosa was higher too. Besides that, the small size of Anadara granosa was more resistant.
\end{abstract}

Keywords. Biofouling, duration time, electrical current, marine bivalve, salinity, simple ICAF system.

\footnotetext{
*Corresponding author: hermankelautan@gmail.com, hermanp@oe.its.ac.id
} 


\section{Introduction}

The use of sea chest on ship's hull below the waterline is required for steel ships or wooden ships with engine installed inside their hull (onboard engine). The sea water requirement can be fulfilled from the sea chest. The sea water is needed as coolant for main engine and auxiliary engine, for ballast purposes, fire extinguisher system, and many more. Generally, sea chests are placed on two places at different height due to the ship sail through different seawater depth.

Two types of sea chests are connected by main pipe that has a controlling valve. If the ship sail through deep seawater, the sea chest on the bottom will be used. On the other hand, if the ship must sail through shallow seawater with mud (or river), the sea chest on the side (bilge) will be used. This condition can apply to avoid mud that is sucked so that it can damage the pumps and make clogging on the piping system installation [1].

Besides that, the fouling can also accumulate inside the piping system, especially pipes which channel sea water as coolant. The fouling can clog the fluid flow, damage the strainer and heat exchanger. The mitigation to this fouling should be applied due to fouling is an adverse problem. Fouling occurred on the surface of ship's hull, it can increase the ship's resistance [2].

The bioaccumulation of marine organisms on the surfaces of submerged or semisubmerged, natural or artificial objects is called marine biofouling [3]. The types of biofouling commonly are founded and accumulated on sea chest. Some types of organism that attached on sea chest are barnacles, Asia green mussel (Perna viridis) and Arcuatula senhousia [4]. According to Anderson et al. (2003) [5], marine organisms can cause biofouling is estimated may exceed 2500 species. Some species have tendency to attach on surfaces, settle and grow on them. These marine organisms are named marine foulers and may mainly be classified into micro and macro foulers [6]. According to Frey et al. [2014) [7], some dominated communities of marine organism can cause biofouling on ship were arthropods (primarily barnacles and amphipods (63\% of sea-chests), molluscs (bivalves and gastropods, $55 \%$ ), cnidarians (primarily hydrozoans, $45 \%$ ), polychaetes $(45 \%)$, and bryozoans $(30 \%)$ in Canada.

Biofouling can be divided into two different categories in term of coarseness namely, micro-fouling (bacteria and diatomic biofilms) and macro-fouling. Micro fouling is biofouling that is caused by bacterial colonization, diatoms and microalgae) through the formation of biofilm. Macro fouling is biofouling that is caused through the attachment of destructive macroorganisms [8]. Macro fouling groups commonly found include: Mollusca, bryozoa, tunicate, barnacles, bryozoans, mussels, and tube worms. The first three groups are the largest and most numerous organisms [9]. Biofouling costs billions of dollars per a year to prevent and maintenance at the global shipping industry.

An mitigation alternative is introduced to prevent biofouling. The Impressed Current Anti Fouling (ICAF) can be used to prevent or to suspend the growth of biofouling, such as barnacles, clams, seaweeds (algae), and other marine plant organisms. Based on our earlier research, ICAF system have ability to decrease the number cells of bacteria Pseudomonas fluorescens with reached $98.5 \%$ - 99.9\% [10]. The percentages of populasion reduction on Vibrio alginolyticus were $87.3 \%$ - $99.4 \%$ with the concentration of $\mathrm{Cu}^{2+}$ ions during the operation of the simple ICAF system reached $4.3 \mathrm{mg} / \mathrm{L}$ to $18.3 \mathrm{mg} / \mathrm{L}$ [11]. According to our other previous study, the decreasing of Chlorella Vulgaris cell number with the highest percentage of $99.98 \%$ at electrical current of $1 \mathrm{~A}$, duration time of $10 \mathrm{~min}$ and concentration of $\mathrm{Cu}(17.9 \pm 0.07 \mathrm{mg} / \mathrm{L})$ [12]. The highest population reduction occurred in Isochrysis galbana and Botryococcus sp reached $77.5 \%$ and $50 \%$, respectively. The highest concentration of $\mathrm{Cu}$ that was produced during the operation of the simple ICAF system reached $4.08 \pm \mathrm{mg} / \mathrm{L}$ [13]. 
The purpose of study was to determine the effects of electrical current, duration time, salinity on Anadara granosa death in simple ICAF system with high-strength low-alloy (HSLA) AH36 steel was as a cathode and copper was as an anode. Copper was chosen due to it was known as an inhibitor for biofouling [14] and based on Ong and Din (2001) [15], $\mathrm{Cu}$ was found to be toxic to the clams.

\section{Materials and Methods}

\subsection{Materials Preparation}

HSLA material was usually applied in the field of marine buildings or ships the cathode with size $15 \times 15 \times 1 \mathrm{~cm}$ used material of HSLA AH36 steel meanwhile the anode with dimension of $15 \times 15 \times 1 \mathrm{~cm}$ used the metal of $\mathrm{Cu}$. Fig 1 showed the material for (a) cathode and (b) anode.

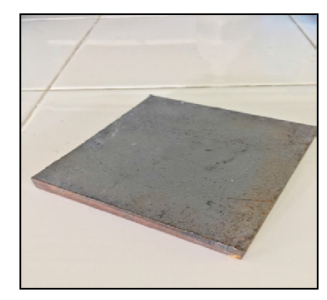

(a)

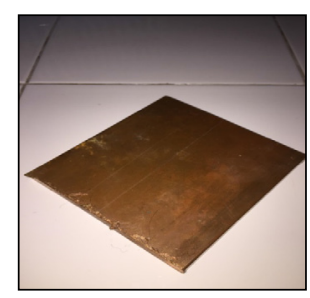

(b)

Fig. 1. The material for (a) cathode and (b) anode

\subsection{Simple ICAF System Reactor}

The design of simple ICAF system was conducted based on our earlier research $[9,10,11,12]$. The simple ICAF system was applied using the DC current due to the anode and cathode supply must be differentiated between positive and negative current sources.

\subsection{Marine Bivalve Preparation}

Marine bivalve molluscs that was used in this study was blood clams (Anadara granosa). There were 10 blood clams at 1 reactor for each treatment so that total number of blood clams were 30 for $1-2 \mathrm{~cm}$ of shell size and 30 for $2-3 \mathrm{~cm}$ of shell size. The blood clams were collected at Kenjeran Beach. After that, all blood clams were cleaned. And then, those were acclimatization at laboratory of Environmental Remediation at campus of ITS before those were used for research. Fig. 2 showed the blood clams. 


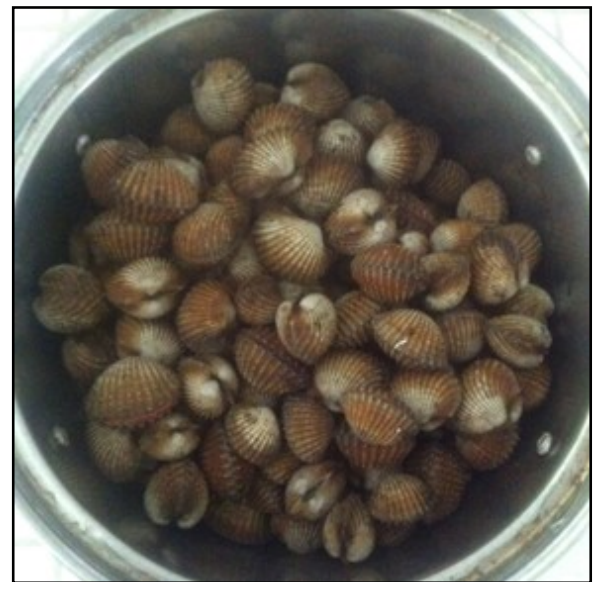

Fig. 2. Anadara granosa acclimatization

\subsection{Preparation of Artificial Seawater}

Based on our previous study, the chemical composition of seawater replacement is in accordance with ASTM D1141-90 (1994) [16-18]. The variations of salinity were $33 \%$, $35 \%$ and $37 \%$.

\subsection{Running of Simple ICAF System Reactor}

Operation of ICAF system were carried out on the duration time variations (1,3,5,7 dan 9 h), variations of salinity (33\%, 35\%o and 37\%o) and the size of shell $(1-2 \mathrm{~cm}$ and $2-3 \mathrm{~cm})$. The electrical current was set at 1.5 Ampere. The main parameter was the death of Anadara granosa after operation of simple ICAF system. Fig 3 described the running of simple ICAF system on Anadara granosa. The ion $\mathrm{Cu}$ concentration were analyzed using Atomic Absorption Spectrophotometer (AAS).

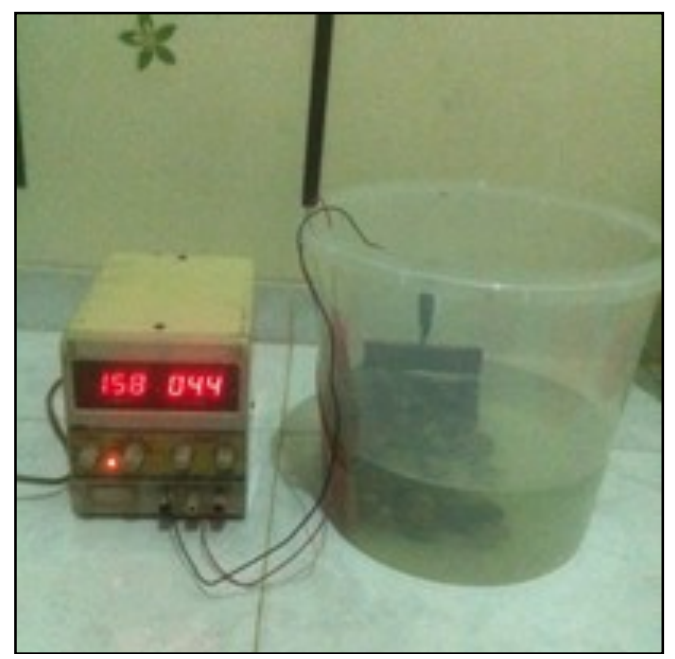

Fig. 3. The running of simple ICAF system on Anadara granosa. 


\subsection{Determination of Parameters}

The death of Anadara granosa was conducted using direct observation. The direct observation was carried out by opening the shells one by one. The death of mollusc can be confirmed by looking the response from the mollusc. If the mollusc showed no response when it was pierced, it indicated that the mollusc was dead. Besides that, there was white slime inside the mollusc.

\subsection{Statistical Analysis}

The experimental data of size shell, salinity and duration time on Anadara granosa death accumulation response during operation of simple ICAF system reactor were subjected to an analysis of variance (ANOVA) using SPSS Statistics for Windows version 21.0 (SPSS, Inc., Chicago, IL). Statistical significance was defined as $\mathrm{p}<0.05$.

\section{Results and Discussion}

Fig. 4 depicted the death of Anadara granosa during operation of simple ICAF system at current electrical of $1.5 \mathrm{~A}$. Based on figure, it was not found number of Anadara granosa death at $1 \mathrm{~h}$ after simple ICAF system running. The death accumulation occurred at $3 \mathrm{~h}$ after simple ICAF system running. However, it showed the number of Anadara granosa death increased when duration time increased both at shell size of $1-2 \mathrm{~cm}$ and $3-2 \mathrm{~cm}$, respectively.

The death accumulation on Anadara granosa with shell size of 1-2 cm reached $10 \%$ at $33 \%$ after simple ICAF system running of $7 \mathrm{~h}$. Meanwhile, the condition showed a difference in salinity of $35 \%$ and $37 \%$. The highest of Anadara granosa death with shell size of $1-2 \mathrm{~cm}$ was $50 \%$ at salinity of $35 \%$ and $37 \%$, respectively for $9 \mathrm{~h}$ of duration time. Meanwhile, the Anadara granosa death at salinity of $33 \%$ was $20 \%$ for the similar time, i.e $9 \mathrm{~h}$.

Based on the data, the death accumulation of Anadara granosa with shell size of $2-3 \mathrm{~cm}$ was $80 \%$ at salinity of $33 \%$ for $9 \mathrm{~h}$. It reached the highest of death accumulation (90\%) at salinity of $35 \%$ and $37 \%$, respectively for $9 \mathrm{~h}$ of duration time.

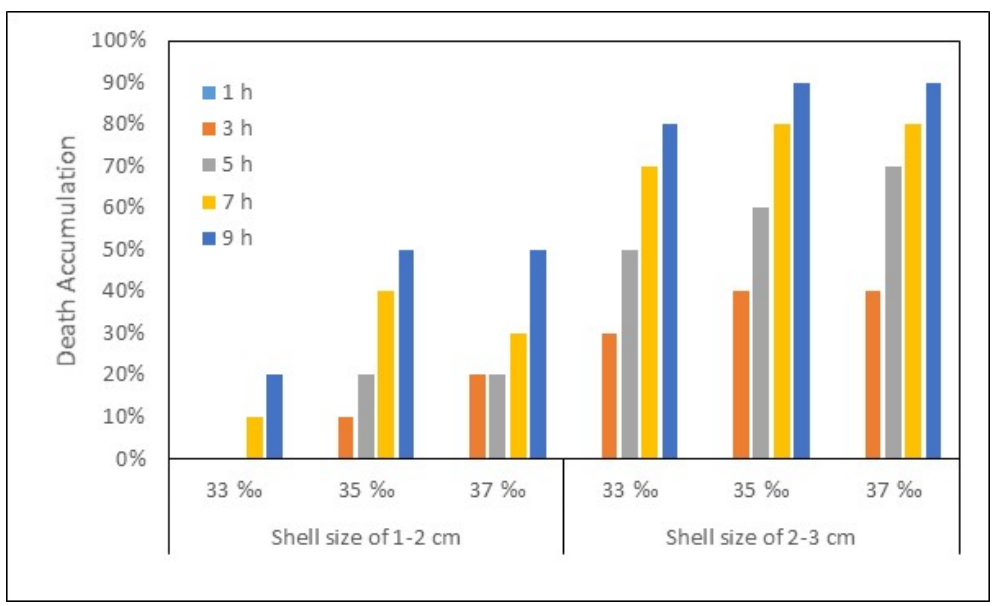


Fig. 4. The death of Anadara granosa during operation of simple ICAF system

Based on statistical analysis using ANOVA, the death accumulation of Anadara granosa with shell size of $1-2 \mathrm{~cm}$ between time variation and salinity was significant $(\mathrm{p}<0.05)$ during operation of simple ICAF system. Based on result analysis using Tukey HSD, the death accumulation of Anadara granosa at between salinity of 33\%o and 35\% was significant ( $p>0.05$ ). It was similary for between salinity of 33\%o and 35\%. However, it was no significant $(\mathrm{p}>0.05)$ for between salinity of $35 \%$ and $37 \%$. It explained that the similarity of death accumulation of Anadara granosa at salinity of 35\% and 37\%.

Based on the result analysis using Tukey HSD, the duration of time of $1 \mathrm{~h}$ between $7 \mathrm{~h}$ on death accumulation of Anadara granosa showed a significant $(\mathrm{p}<0.05)$. It was similary on the duration of time of $1 \mathrm{~h}$ between $9 \mathrm{~h}$. However, the duration of time of $1 \mathrm{~h}$ between 3 $\mathrm{h}$ and $5 \mathrm{~h}$ on death accumulation of Anadara granosa showed no significant $(\mathrm{p}>0.05)$. It indicated that the death accumulation of Anadara granosa has a similarity value.

The results of analysis ANOVA on death accumulation of Anadara granosa with shell size of $2-3 \mathrm{~cm}$ showed a significant $(\mathrm{p}<0.05)$ on variation of duration time and salinity. After that, based on the result analysis using Tukey HSD, it showed the similary result with the size shell of $1-2 \mathrm{~cm}$.

Based on the results of ANOVA analysis for shell size of $1-2 \mathrm{~cm}$ between $2-3 \mathrm{~cm}$ at variation of duration time and salinity, it showed that the duration time and salinity were a significant $(\mathrm{p}<0.05)$ on mortality of Anadara granosa during simple ICAF system running. It indicated that shell size of Anadara granosa was as influential factor for mortality of Anadara granosa. According to Yap et al., (2003) [19], the shells have ability to accumulate a wide range of metals due to it have different mineralogies and chemistries in the shells.

The measured concentration of $\mathrm{Cu}$ during the operation of the simple ICAF reached $55.53 \mathrm{mg} / \mathrm{L}$ to $321.70 \mathrm{mg} / \mathrm{L}$ at salinity of $33 \%$. It was $56.25 \mathrm{mg} / \mathrm{L}$ to $560.25 \mathrm{mg} / \mathrm{L}$ at salinity of $35 \%$ and it ranged $72.65 \mathrm{mg} / \mathrm{L}$ to $667.85 \mathrm{mg} / \mathrm{L}$ at salinity of $37 \%$. Based on the figure 5 , the concentration of $\mathrm{Cu}$ ion increased with time and salinity increasing. The electrical current increased when the salinity increased due to sodium and chloride ions can be a conductor. Salinity content of sodium chloride. Sodium chloride is an electrolyte, and when this is dissolved in water to form salt water, it becomes sodium ions $\left(\mathrm{Na}^{+}\right)$and chloride ions $\left(\mathrm{Cl}^{-}\right)$, each of which is a corpuscle that conducts electricity. It indicated that the increasing ion $\mathrm{Cu}$ production affected with the long of duration time and electrical current that occurred in the saline water.

Although cockle Anadara granosa was a typically intertidal species which naturally lives in an area with soft mud and fine sand. In some area, they can live in $20 \mathrm{~m}$ water depth but commonly concentrate in the littoral area and estuaries [20].

Blood cockles can have a best live under calm conditions, especially in shallow inlet bays, with soft and flocculent mud with salinity ranging from 18 to $30 \%$ oo $[21,22,23]$. Anadara granosa also live in estuaries and can tolerate some changes in salinity for normal condition [24]. This condition can be changed due to ion $\mathrm{Cu}$ in the seawater.

Based on Liu at al. (2012) [25], the LC50 value of $\mathrm{Cu}$ concentration can cause kill Tegilarca granosa was $26.27 \mathrm{mg} / \mathrm{L}$ at $24 \mathrm{~h}$. The measurement parameter at acute test is mortality number of dead individual and it was indicated as LC50 (lethal concentration). LC50 is defined as the concentration at which 50\% lethal of the population of experimental organisms. According to Rombke and Moltmann (1996) [26], mortality data usually from acute tests is discrete data, with values which may range between 0 and $100 \%$. 


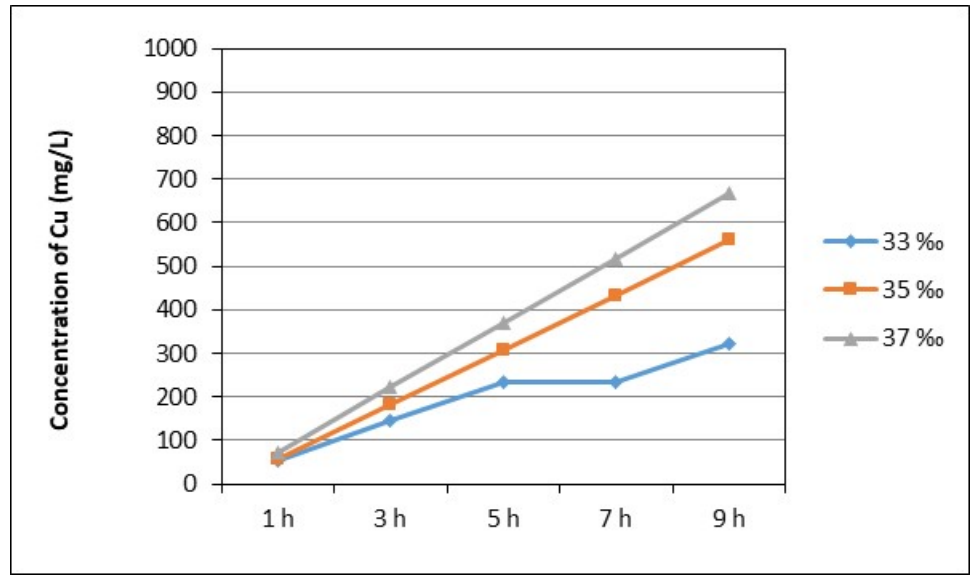

Fig. 5. The Concentration of Cu during Simple ICAF System Operation

Based on statistical analysis using ANOVA, the difference of $\mathrm{Cu}$ ion concentration between electrical current and time variation was no significant $(p>0.05)$. It similar with of number cells reduction percentages. It also showed no significant $(p>0.05)$ due to the percentages showed high reduction at all variation

\section{Conclusions}

The death accumulation of Anadara granosa with shell size of 2-3 cm showed the highest percentage of $90 \%$ at electrical current of $1.5 \mathrm{~A}$, duration time of $9 \mathrm{~h}$, and salinity of $37 \%$. Meanwhile the smallest percentage of Anadara granosa death reached $10 \%$ at electrical current of $1.5 \mathrm{~A}$, duration time of $7 \mathrm{~h}$, and salinity of $33 \%$ o for shell size of $1-2 \mathrm{~cm}$. In conclusion, duration time and salinity were higher so that the death of Anadara granosa was higher too. Besides that, the small size of Anadara granosa was more resistant.

\section{Acknowledgement}

The author would like to thank Kementerian Riset dan Teknologi/ Badan Riset dan Inovasi Nasional, Indonesia through scheme of Penelitian Dasar Unggulan Perguruan Tinggi - third year research, PDUPT 2020 for funding this research with No of contract, 3/E1/KP.PTNBH/2020, and No of amendment contract, 3/AMD/E1/KP.PTNBH/2020, and No. 1170/PKS/ITS/2020.

\section{References}

1. B. Utomo. 2012. Study Program of Diploma III, Naval Engineering, Faculty of Engineering. Universitas Diponegoro Semarang. (2012)

2. F. Marison. Department of Naval Engineering, Institut Teknologi Sepuluh Nopember, Surabaya. (2012)

3. J.A. Lewis. Materials Forum. 22. p. 41-61. (1998)

4. K.M. Neil, H. Stafford. Queensland Department of Primary Industries and Fisheries and CRC Reef, report to the Australian Government Department of Agriculture, Fisheries and Forestry, p 30. (2005)

5. C. Anderson, M. Atlar, M. Callow, M. Candries, A. Milne, R.L Townsin. Science and Technology (IMarEST). Part B: Journal of Marine Design and Operations. 4. p. 11-23. (2003) 
6. M. Taylan. International Conference on Ship Drag Reduction, SMOOTH-SHIPS. Istanbul, 20-21 May 2010. Istanbul. (2010)

7. M.A. Frey, N. Simard, D. David, Robichaud, L. Jennifer. Martin and T.W. Therriault. Management of Biological Invasions, 5(1) 21-30 (2014)

8. A.I. Railkin. Marine Biofouling Colonization Processes and Defence. CRC Press, Florida. (2004)

9. A.F. Ruslan. Kepadatan Dan Keragaman Macrobiofouling Pada Dermaga Beton Dan Dermaga Kayu Di Pulau Balanglompo. Kec. Mattiro Sompe. Kab. Pangkep. Jurusan Ilmu Kelautan Fakultas Ilmu Kelautan Dan Perikanan Universitas Hasanuddin, Makassar. (2014)

10. H. Pratikno, H.S Titah, M.D.R Mauludin, System Impressed Current Anti Fouling (ICAF) Against Micro Fouling (Bacteria) on Ship's Cooling System. MATEC Web of Conferences 177 (2018)

11. H. Pratikno, H.S. Titah, Handayanu. Int. J. of Civil Eng. and Technol. 10(1),15071514 (2019)

12. H. Pratikno, H.S. Titah, Handayanu. International Conference on Energy, Environment, Epidemiology and Information System (ICENIS), E3S Web of Conferences 125 (2019)

13. H. Pratikno, H.S. Titah, Handayanu. Journal of Ecological Engineering. 21(2): 80-88. (2020)

14. H. Effendi, Telaah Kualitas Air bagi Pengelolaan Sumber Daya dan Lingkungan Perairan. 5th Edition. Yogjakarta: Kanisius (2003)

15. Ong, E., Din, Z. Bull. Environ. Contam. Toxicol. 66, 86-93 (2001).

16. H. Pratikno, H. S. Titah and M. D. R. Mauludin. MATEC Web of Conferences 177, 01013 (2018)

17. H. Pratikno, H. S. Titah and Handayanu. International Journal of Civil Engineering and Technology, 10(1), 1507-1514 (2019)

18. ASTM D1 141-90. Chemical composition of artificial seawater. (1990)

19. Yap, C.K, Ismail, A. and Tan, S.G. Estuarine, Coastal and Shelf Science, 57, 623-630. (2003)

20. W. X. Liu, X. D. Li, Z. G. Shen, D. C. Wang, O. W. H. Wai, and Y. S. Li. Environmental Pollution, 121(3)377-388. (2003)

21. Ng, F.O. Cockle culture, SAFIS Manual No 13, Fisheries Research Institute, Southeast Asian Fisheries Development Center, Gelugor, Penang, Malaysia (pp. 1-22). (1984)

22. Panthasali, D. and Soong, M.K. Indo-Pacific Fisheries Council, 18(11), 26-31. (1985).

23. FAO, Species Fact Sheets, Anadara granosa (Linnaeus, 1758), Food and Agriculture Organization of the United Nations, Fisheries and Aquaculture Department, (2019)

24. Yap, C.K.1*, Muhamad Azlan, A.G.1, Cheng, W.H. and S.G. Tan. Pertanika J. Trop. Agric. Sci. 34 (1): 75 - 82. (2011)

25. G. X. Liu, M. A. Shu, X. L. Chai, Y. Q. Shao, H. X. Wu, C. S. Sun, S. B. Yang. Bull Environ Contam Toxicol 92:71-74(2014)

26. J. Rombke and J.F. Moltmann. Applied Ecotoxicology. CRC/Lewis Publishers, UK., ISBN-13: 9781566700702, Pages: 282. (1996) 